\title{
ALLUVIAL DEPOSITS AS A SUBSOIL AND MATERIAL FOR BASIC HYDRO-TECHNICAL CONSTRUCTIONS
}

\author{
Jędrzej Wierzbicki' ${ }^{1}$, Katarzyna Stefaniak ${ }^{2}$ \\ 1 Department of Engineering Geology and Geotechnics, Adam Mickiewicz University in Poznań, Maków \\ Polnych Str. 16, 61-606 Poznań, Poland, e-mail: jwi@amu.edu.pl \\ 2 Institute of Construction and Geoengineering, Poznań University of Life Sciences, Piątkowska Str. 94, 60-649 \\ Poznań, Poland, e-mail: kst@up.poznan.pl
}

Received: 2015.09.16

Accepted: 2015.10.06

Published: 2015.11.10

\begin{abstract}
The article presents an analysis of geotechnical parameters of the alluvial deposit (the areas of the Vistula and Warta river valleys) with a view to using the soil as an earth construction material and as a foundation for buildings constructed on the grounds tested. Strength and deformation parameters of the subsoil tested were identified by the CPTU (cone penetration test) and DMT (flat dilatometer test) methods, as well as by the vane test (VT). The article includes the analysis of overconsolidation process of the soil tested and a formula for the identification of the overconsolidation ratio OCR. Equation 4 reflects the relation between the undrained shear strength and plasticity of the silts analyzed and the OCR value. The analysis resulted in the determination of the $\mathrm{N}_{\mathrm{kt}}$ coefficient, which might be used to identify the undrained shear strength of both sediments tested. On the basis of a detailed analysis of changes in terms of the constrained oedometric modulus $\mathrm{M}_{0}$, the relations between the said modulus, the liquidity index and the OCR value were identified. Mayne's formula (1995) was used to determine the $\mathrm{M}_{0}$ modulus from the CPTU test. The usefulness of the alluvial deposit as an earth construction material was analysed after their structure had been destroyed and compacted with a Proctor apparatus. In cases of samples characterized by different water content and soil particle density, the analysis of changes in terms of cohesion and the internal friction angle proved that these parameters are influenced by the soil phase composition. On the basis of the tests, it was concluded that the most desirable shear strength parameters are achieved when the silt is compacted below the optimum water content.
\end{abstract}

Keywords: silty soils, strength, deformation, overconsolidation.

\section{INTRODUCTION}

A considerable part of the subsoil structure in European Lowlands is composed of alluvial deposits. These deposits fill contemporary river valleys as well as previous vast ice-marginal valleys of rivers and glacial channels. A proper water management, including the flood-protection activity, requires comprehensive actions on a broad scale, including building hydro-engineering constructions. In case of large dams and reservoirs, a detailed geological and geotechnical investigations are commonly carried out. Unfortunately, the most of basic hydro-technical constructions, as for example flood banks, are treated as low costs projects, and the funds for them are insufficient on the proper geoengineering investigations. Coupled with the complex soil composition of alluvial deposits, it could implicate serious problems during constructing and using these facilities.

There are two issues that seem to be crucial for the proper description of geotechnical properties of alluvial soils. One of them is the evaluation of the properties of these soils, and above all the interpretation of the characteristics determined by in-situ and laboratory studies, when these soils constitute a foundation for earthen structures. The other problem is the use of these 
soils as a material for earthen structures. In order to clarify these issues, analyses were conducted on normally consolidated alluvial deposits, found in the areas of the Vistula and Warta river valleysand investigated during in situ and laboratory tests. For the evaluation of the properties of selected deposits in the geostatic state of stress (in situ), cone penetration test (CPTU) and dilatometer test (DMT) methods were used. The laboratory Proctor and Tri-axial Tests allowed to evaluate the geotechnical properties of compacted alluvial deposit used for the man-made constructions. The results of those investigations are presented in this paper.

\section{GEOTECHNICAL VARIABILITY OF RIVER DEPOSITS}

Alluvial deposits often vary form a very complex subsoil. This is also due to different deposition conditions (as different as flood plain and channel environments) which causes in sand, silt (mud) and clay layers occurred within the valley fulfils, and strong influence of erosion on a continuity of alluvial layers.

Strong variability of geotechnical parameters of alluvials was described, among others, by Wierzbicki and Smaga [2014], who found that only $10 \%$ of the investigated profiles can be treadted as geotechnicaly repeatable on the area of less than $0.5 \mathrm{~km}^{2}$. Moreover, Wierzbicki [2005] proposed a model of part of the Vistula river vallley which clearly shows both the differences in the shear strength parameters of alluvials along the valley and the changes in these parameters due to long term flood conditions (Figure 1).

The observed strong variability of river valley deposits emphasizes the need of precise and accurate investigations in the case of geotechnical description of the site, even if the engineering task seems to be simple and easy.

\section{SHEAR STRENGTH PARAMETERS}

The shear strength of a subsoil of the finegrained type in the geostatic state of stress is described by the undrained shear strength $\mathrm{Su}$ or Coulombian parameters expressed in effective stresses $\phi^{\prime}, c^{\prime}$ [Lunne et al. 1997, Senneset et al. 1982, Sandven et al. 1988].

The function that defines undrained shear strength in the geostatic state of stress for a layer

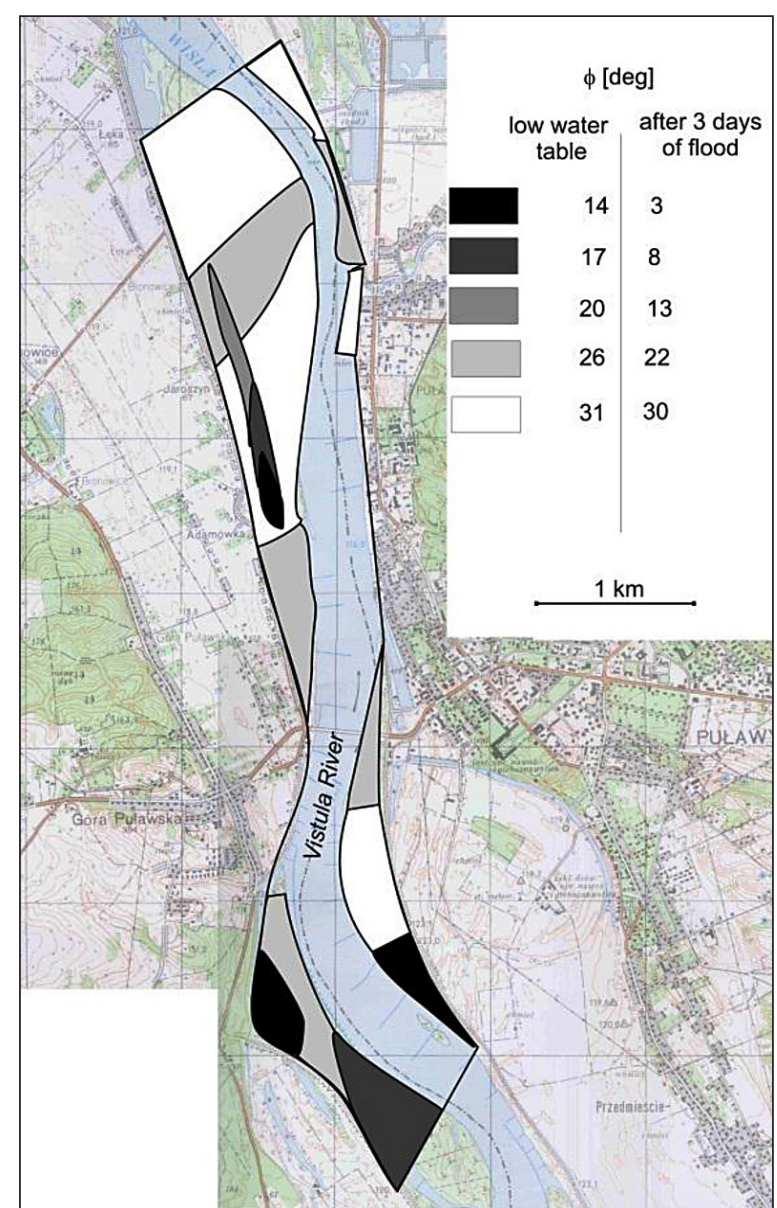

Figure 1. The map of values of friction angle $\phi$ of alluvial deposits of Vistula valley near Puławy, before and during a flood

of alluvial soil, homogenous in terms of grain size distribution, it may be described in the form:

$$
s_{u}=f\left(\sigma_{\mathrm{v} 0}, L I, O C R, \theta\right)
$$

where: $L I$ - liquidity index, $O C R$ - overconsolidation ratio, $\theta$ - coefficient of macrostructure of the soil.

In case of alluvial soils of organic origin, equation (1) has to be supplemented with a variable defining the content of organic particles. The function (Eq. 1) is dimensionally non-uniform. It may be transformed to a uniform dimensional form by the normalization of su, then:

$$
s_{u} / \sigma_{\mathrm{v} 0}=f(L I, O C R, \theta)
$$

Several highly significant conclusions for the evaluation of undrained shear strength of alluvial soils result from equation (1). A solution of function (1) has not been given to date. Generally, partial functions are determined, which represent the so-called local correlations and belong to a family of functions for different types of alluvial soils. The effect of structure on undrained shear 
strength is most frequently presented with a sensitivity index $-S_{t}$. This index may also be determined from CPTU with the function [Lunne et al. 1997, Schnaid 2009, Robertson 2009]:

$$
S_{t}=\frac{N_{s}}{R_{f}}
$$

where: $N_{S}$ - constant, recommended average value of 7.5.

For the soils tested, the $S_{t}$ coefficient was 3.8 (NC) in the Warta valley, and 4.0 in the Vistula valley. The values of this coefficient indicate that these soils are classified among soils of medium sensitivity.

A very important conclusion concerning potential in-situ testing methods may be drawn from function (1). The value of $s_{u}$ is not determined directly from CPTU and DMT, and so the value obtained from those tests has to be referred through correction formulas to tests directly determining $\mathrm{su}$, such as the vane test, or to laboratory analysis [Mayne, 2009]. Therefore appropriate $N_{k t}$ coefficientneed to be determined for CPTU. The quality of these coefficients will determine the quality of undrained shear strength determined in situ [Młynarek 2010].

In the case of the deposits tested, undrained shear strength was referred to the critical shear strength from VT $-\tau_{\text {umax }}$. In the solution of equation (2) for these soils a multiple linear regression method was applied, which yielded the following relationship:

$s_{u}=58.15-144.6 L I+34.74 O C R ; R^{2}=0.91$

The value of the multiple regression coefficient indicates that as much as $91 \%$ variation in undrained shear strength is related to the variation in OCR and the liquidity index.

Partial functions resulting from equation (1) are of a significant practical importance, since they determine the relationship between undrained shear strength and changes in the liquidity index of deposits in the subsoil or OCR, or possibly the overburden stress $\sigma_{v 0}$ (Figures. 2, 3, 4). Changes in undrained shear strength with a change in the stress $\sigma \mathrm{v} 0$ show a linear trend, similarly as for fine-grained soils [Robertson 2009]. The relationship between a change in $s_{u}$ and the liquidity index, however, is described by an exponential function, approaching asymptotically the value of shear strength at the liquid limit. This value is close to $2 \mathrm{kPa}$ for all fine-grained soils [Młynarek 1970, Horn 1964]. Figure 3 shows

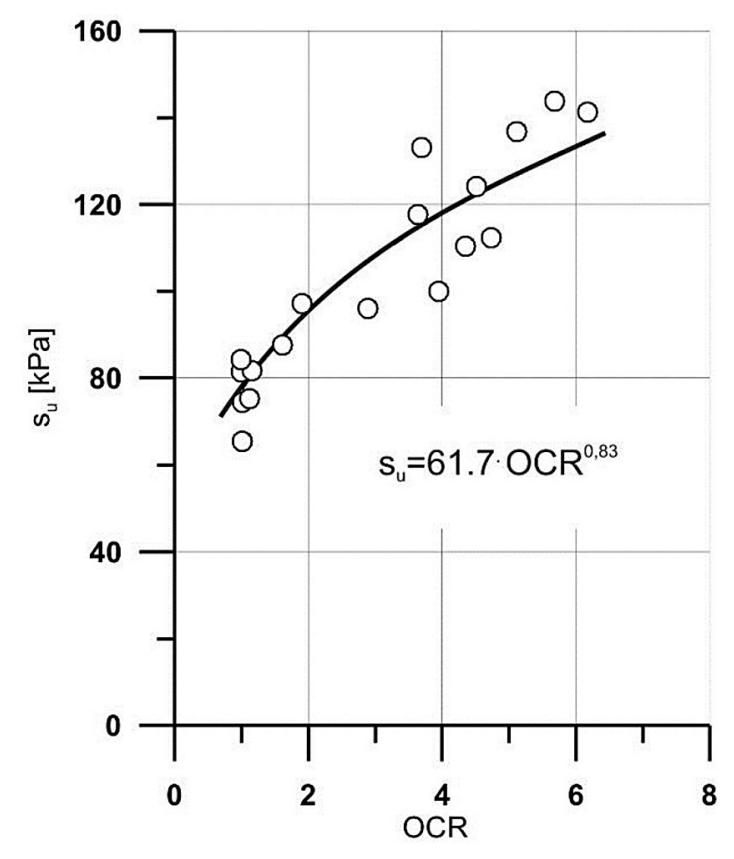

Figure 2. Relationship between undrained shear strength $\left(s_{u}\right)$ and overconsolidation ratio (OCR) for Warta site [Młynarek et al. 2012]

that the trend of changes in $s_{u}$ related to changes in the liquidity index is very similar and almost identical to changes from the vane test. In order to determine the trend of changes in $s_{u}$ related to changes in the liquidity index and the consistency of these changes with the changes in $\tau_{\max }$ with the liquidity index, the values of undrained shear

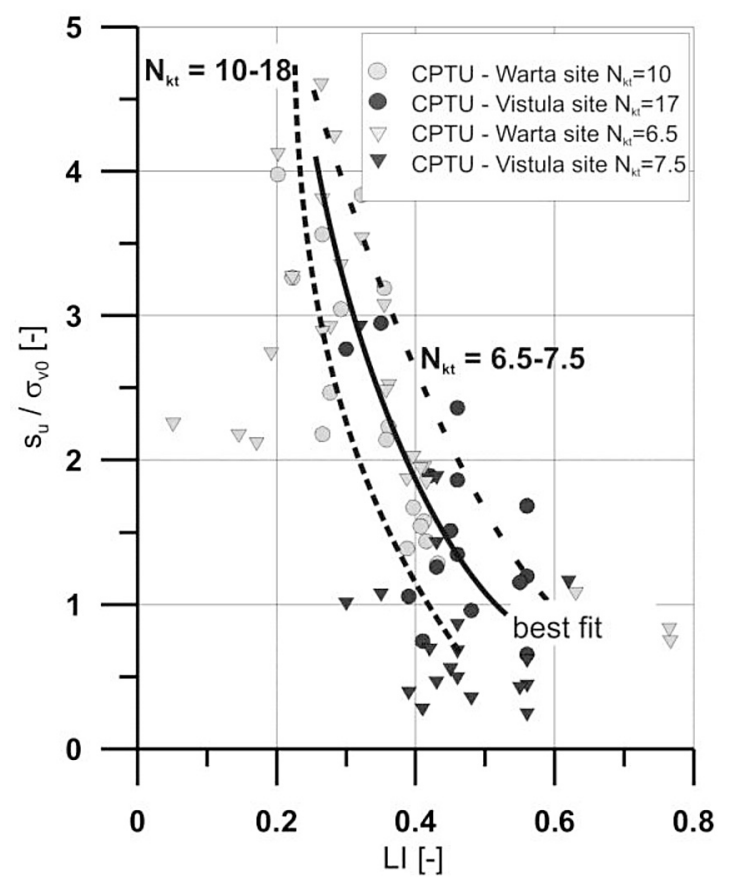

Figure 3. Relationship between normalized undrained shear strength $s_{u}$ and liquidity index $L I$ for different $N_{k t}$ values 
strength found in Figure 3 were determined for the coefficient $N_{k t}=10$ (Warta river) and $N_{k t}=17$ (Vistula river). The consistency of trends makes it possible to determine the real value of $N_{k t}$ for the two groups of deposits tested. If undrained shear strength is referred to strength from the vane test, then the values of $N_{k t}$ are 7.5 for alluvial deposits from the Warta valley and 6.5 for alluvial deposits from the Vistula valley.

\section{CONSTRAINED DEFORMATION MODULUS}

The relationship between the constrained modulus $M_{0}$ and the parameters describing properties of alluvial subsoil is described by the same function which determines equation (1). The paper is focused on the analysis of the possibility to calculate constrained moduli $M_{0}$ of silts from CPTU results, which is commonly described by basic Mayne [1995] formula.

Current studies showed that there is a strong relationships between the modulus $\mathrm{M}_{0}$ and preconsolidation pressure $\sigma_{p}$, vertical stress $\sigma_{v 0}^{\prime}$ and liquidity index $L I$, which is highly significant for practical purposes. The analysis of this relationship shows that it needs to be considered as a joint function. The abovementioned effect of overconsolidation effect and liquidity index on the modulus $M_{0}$ seems to be even stronger than

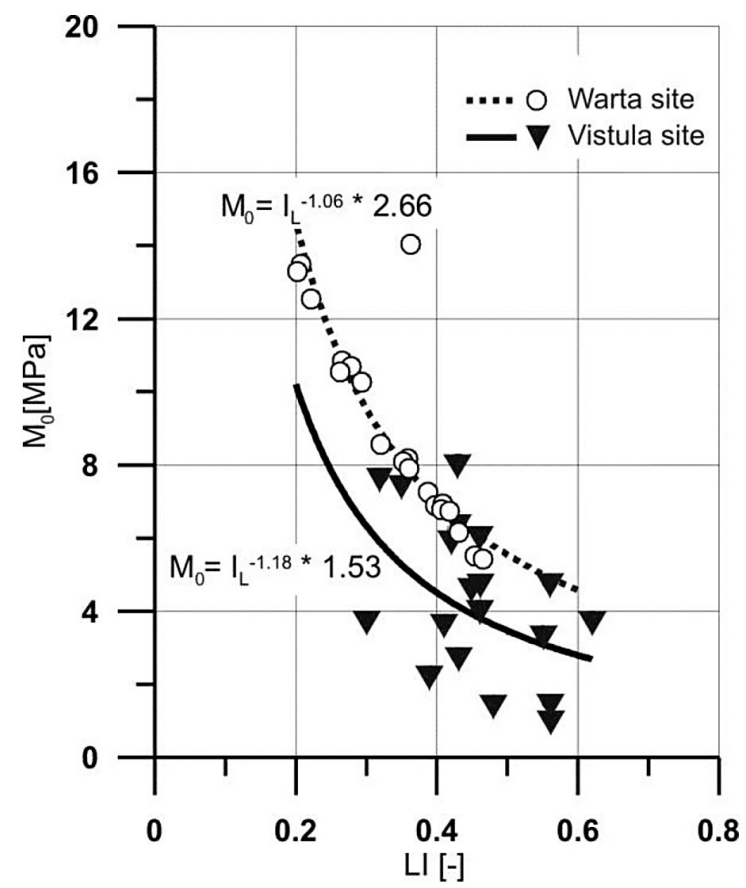

Figure 4. Relationship between constrained modulus $M_{0}$ and liquidity index $L I$ [Młynarek et al. 2012] on undrained shear strength. This fact is very well illustrated in Figures 4 and 5. Moreover, it can be observed that the influence of pre-consolidation pressure on the value of constrained modulus is stronger than in the case of vertical overburden stress. The joint function, describing the relationship between the $M_{0}$ modulus and $\sigma_{p}, \sigma_{v 0}$ and $L I$, takes the form:

$$
M_{0}=22.16-1.16 L I-0.19\left(\sigma_{\mathrm{p}} / \sigma_{\mathrm{v} 0}^{\prime}\right)
$$

Owing to a high variability in grain size distribution and the overconsolidation effect on the value of the constrained modulus, the effect of stresses $\sigma^{\prime}{ }_{v 0}$ on a change of the modulus does not have a functional relationship (Figure 6). This conclusion is confirmed by statistical analysis, since a change in the $\mathrm{M}_{0}$ modulus is caused in as much as $98 \%$ by variation in LI and OCR, and only in $1 \%$ by a change in $\sigma_{\mathrm{v} 0}$ itself. This conclusion is of interest, since in homogenous deposits, which are classified as alluvial deposits, an increase in the value of the $M_{0}$ modulus with an increase in $\sigma_{\mathrm{v} 0}$ is a commonly acknowledged fact. It results from function (5) that the evaluation of changes in the $M_{0}$ modulus for practical solutions requires the construction of a profile in the 1-D or 2-D system for each isolated subsoil layer (a model of subsoil rigidity - [Młynarek et al. 2007, Tumay et al. 2011]) with the use of

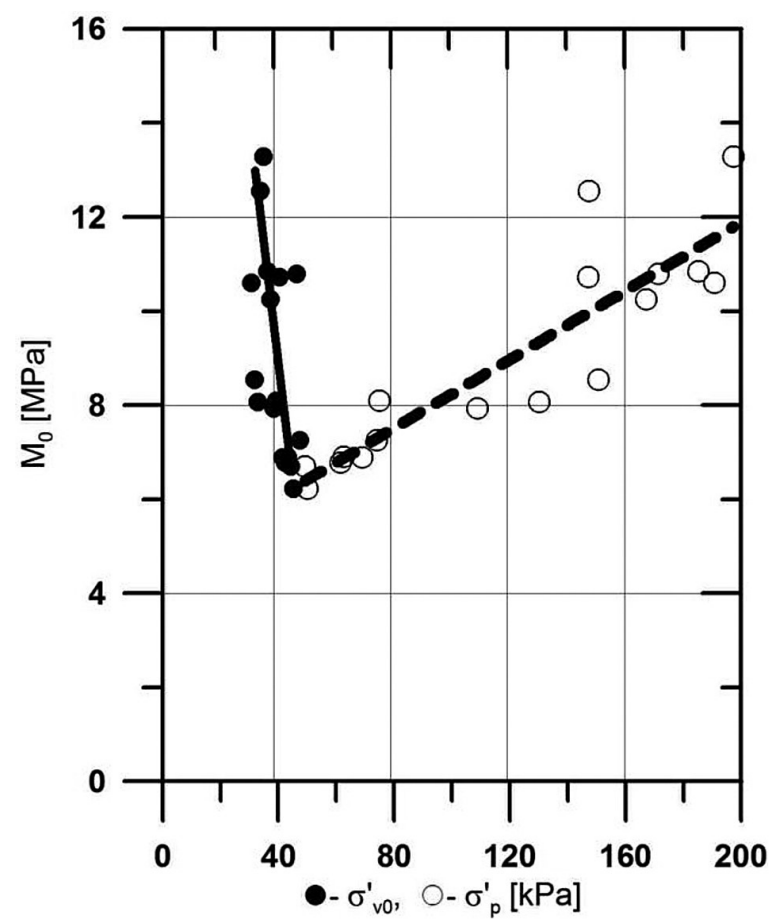

Figure 5. Relationship between constrained modulus $M_{0}$, vertical overburden stress $\sigma^{\prime}$ v0 and pre-consolidation pressure $\sigma_{\mathrm{p}}$ for the Warta test site 


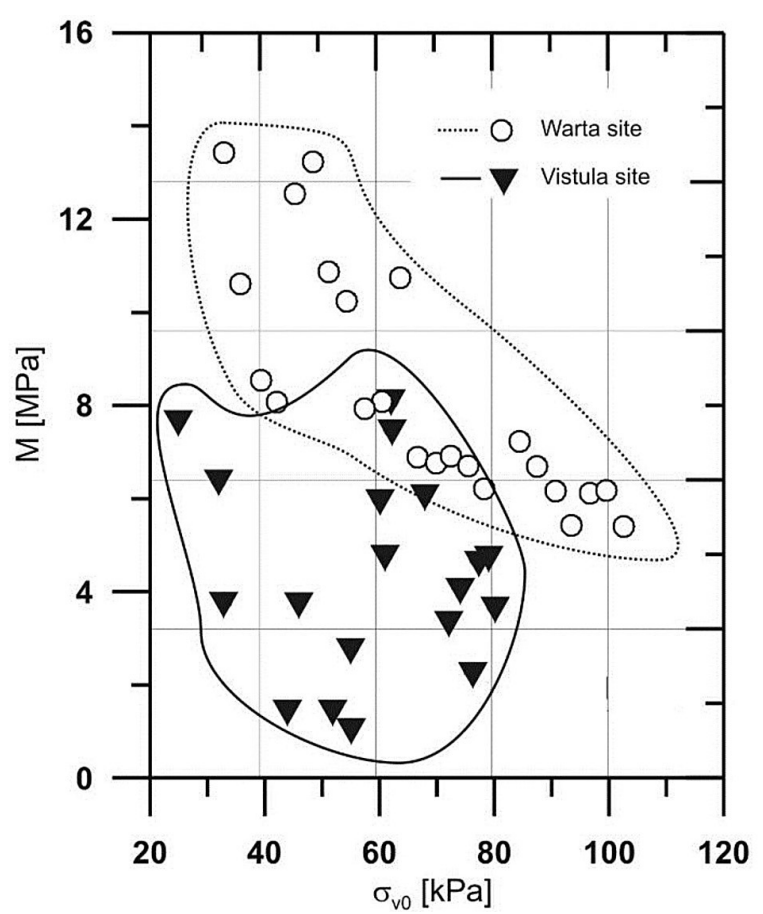

Figure 6. Relationship between constrained modulus $M$ and overburden pressure $\sigma^{\prime}{ }_{\mathrm{v} 0}$.

basic relationships between the cone resistance $q_{c}$ and $M_{0}$ modulus.

\section{ALLUVIAL DEPOSITS AS MATERIAL FOR BASIC HYDRO-TECHNICAL CONSTRUCTIONS}

The Proctor criterion is commonly applied in the evaluation of the suitability of soils for use in earthen structures. One of the criteria for their suitability is the compactibility and the another one is the determination of the most desirable shear strength parameters after the soil is embedded into an earthen structure. The shear strength of alluvial soils classified as silts is described by two parameters which are expressed in total stresses: cohesion $c_{u}$ and internal friction angle $\phi_{u}$. These parameters are understood as random variables, and they are joint random variables (Benjamin \& Cornell 1970, Młynarek et al. 1988), since their variation is influenced by both moisture content w and density $\rho_{\mathrm{d}}$ (Figure 7).

Thus the key questions are as follows: (i) what is the effect of independent variables, i.e. moisture content and density, on both strength parameters and (ii) is the optimal moisture content criterion from the Proctor test a definite criterion for the determination of their most desirable values? To confirm the effect of both variables on cohesion and internal friction angle, we may use a diagram of soil phase composition [Kezdi 1969, Młynarek and Kezdi 1980]. Variables $\rho_{d}$ and w are replaced in this system by the components of the phase composition in the form:

$$
\begin{gathered}
S=\rho_{\mathrm{d}} / \rho_{\mathrm{s}} \cdot 100 \%, \\
V=w \cdot \rho_{d} / \rho_{w} \cdot 100 \%, \\
L=100 \%-(S+V)
\end{gathered}
$$

where: $S$-the share of the skeleton, $V$ - the share of water, $L-$ the share of air, $\rho_{w}$ - density of water, $\rho_{s}-$ specific density of soil solids.

Figure 8 shows that the effect of phase composition on cohesion and the angle of internal friction is clear. Isolines for cohesion and the angle of internal friction may be obtained for different phase compositions in a unit of soil volume, depending on the position of test points on the Proctor curve (Figure 7). It results from the Proctor curve that the silt tested is a soil of good compactibility, since the curve has an evident point of inflexion at the optimal moisture content.

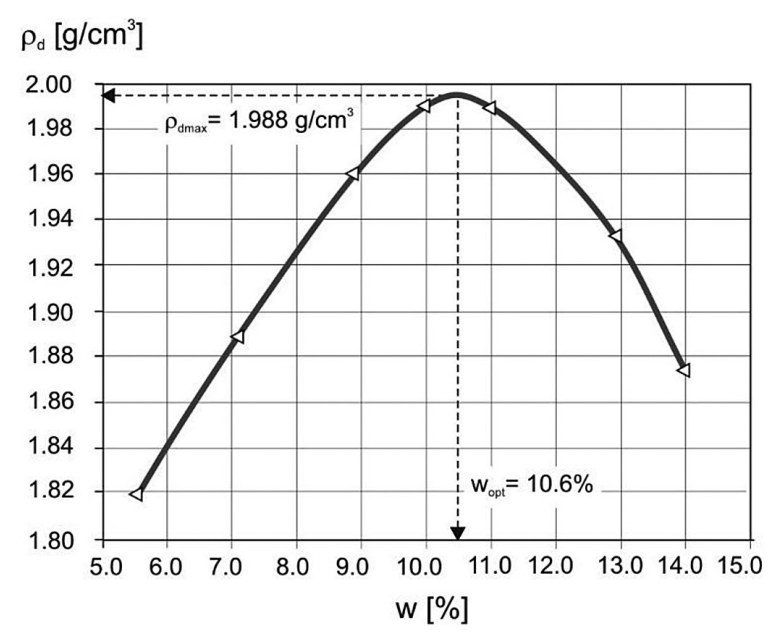

Figure 7. Standard Proctor compaction test results for the alluvial subsoil

However, this point does not correspond to the most desirable shear strength parameters. Thus, in order to obtain the most desirable shear strength parameters of the alluvial soil under analysis, it should be embedded into an earthen structure at a moisture content lower than the optimal level. It is an important statement from a practical point of view, confirming a conclusion presented in the literature on the subject [Wiłun 2000]. It needs to be stressed that the cohesion values obtained above the optimal moisture content are very similar to undrained shear strength from CPTU. 

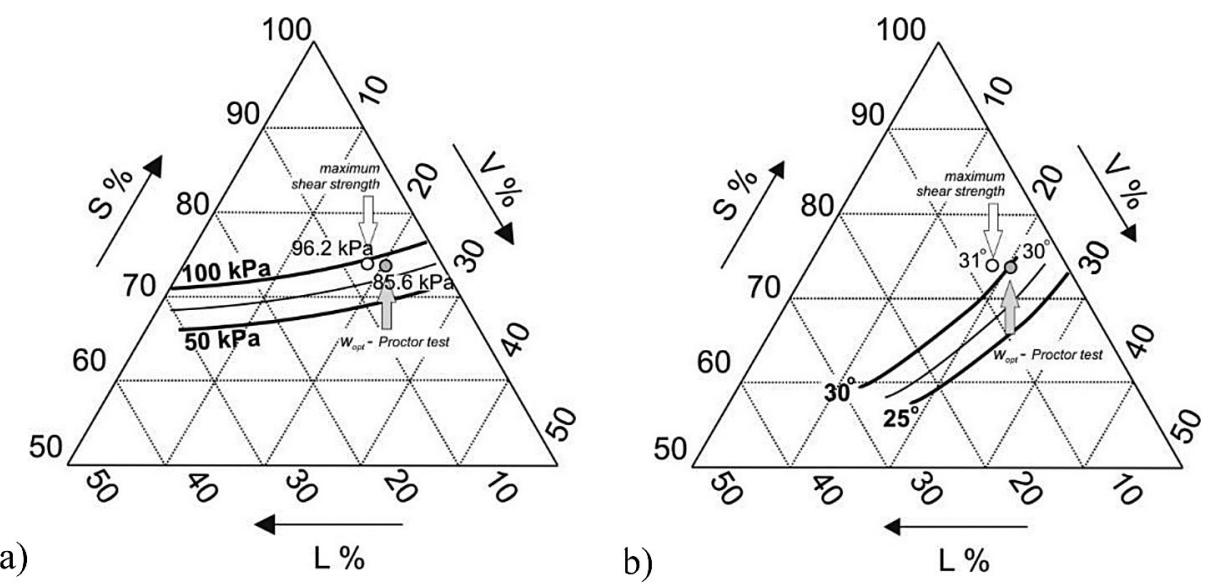

Figure 8. Cohesion a) and angle of internal friction b) as a function of phase composition for alluvial deposits

\section{CONLUSIONS}

1. Alluvial deposits are characterized by high spatial variability in terms of their grain size distribution and state parameters. This fact also results in a considerable spatial variation of strength and deformation parameters in the subsoil, despite a similar genesis. Each alluvial deposit should be considered as a separate interpretation problem for insitu tests.

2. The quasi preconsolidation effect should be taken into consideration in the interpretation of shear strength parameters and constrained moduli of these soils. CPTU seems to be a proper testing method for such a subsoil, and a continuous recording of measured parameters. Despite this, the use of CPTU for design purposes requires to use formulas calibrated for the alluvial soil case.

3. Alluvial soils classified as silts are soils with good compactibility, meeting the criterion for their use in earthen structures. The most desirable shear strength parameters are not found at the optimal moisture content: in the case of the silt tested moisture content below the optimal by approx. $1 \%$ was found. Above this point a rapid decrease in shear strength is observed.

\section{Acknowledgements}

The authors would like to thank prof. Zbigniew Młynarek and HEBO Poznań Ltd. for the inspiring discussion and performance and making available the results of CPTU and SDMT.

\section{REFERENCES}

1. Benjamin J.R. and Cornell C.A. 1970. Probability, statistics, and decision for civil engineers. McGraw-Hill Book Co., New York.

2. Horn A. 1964. Die Scherfestigkeit von Schluff Westdeutschr Verlag. Koln.

3. Kezdi A., Młynarek Z. 1980. Static penetration test results with soils having slight or medium cohesion. Acta Technica Academiae Scientiarum Hungaricae, 90 (3-4), 187-199.

4. Kezdi A. 1969. Handbuch der Bodenmechanik. Akademiai Kiado. Budapest.

5. LunneT., Robertson P.K., Powell J. 1997. Cone penetration testing in geotechnical practice. E\&FN Spon, London.

6. Mayne P.W. 1995. Profiling yield stress in clays by in-situ tests. Transportation Research Record 1479, National Academy Press, Washington, D.C. 43-50.

7. Mayne P.W., Coop M.R., Springman S., Huang A-B., Zornberg J. 2009. State-of-the-art paper (SOA-1): Geomaterial behavior and testing. In: Proc. of $17^{\text {th }}$ Int. Conf. on Soil Mechanics \& Geotechnical Engineering, Vol. 4 (ICSMGE, Alexandria, Egypt), Millpress/IOS Press Rotterdam, 2777-2872.

8. Młynarek Z. 1970. Metoda sondowania statycznego w zastosowaniu do charakterystyki konsystencji i cech wytrzymałościowych gliny piaszczystej. PhD Thesis (in Polish), University of Life Sciences, Poznań.

9. Młynarek Z., Tschuskche W., Sanglerat G. 1988. Accuracy of embankment density assessment of cone penetration test and light dynamic probe. Proc. of ISOPT-1988, Orlando; Balkema, 869-874.

10. Młynarek Z., Wierzbicki J., Wołyński W. 2007.An approach to 3D subsoil model based on CPTU results. Proc. of $14^{\text {th }}$ European Conference on Soil Mechanics and Geotechnical Engineering, Madrid. Vol. 3. Millpress Rotterdam, 1721-1726. 
11. Młynarek Z. 2010. Quality of laboratory and insitu test contribution to risk management. In: Proc. of $14^{\text {th }}$ Danube-European Conference on Geotechnical Engineering, Bratislava, Slovakia.

12. Młynarek Z., Stefaniak K., Wierzbicki J. 2012. Usefulness of alluvial soils for earth constructions. In: Proceedings of $12^{\text {th }}$ Baltic Sea Geotechnical Conference, Rostock 2012.

13. Robertson P.K. 2009. Interpretation of Cone Penetration Testing - a unified approach. Canadian Geotechnical Journal.

14. Sandven R., K. Senneset, N. Janbu 1988. Interpretation of piezocone tests in cohesive soils. In: Proc. ISOPT-1. Orlando, 939-953.

15. Schnaid F. 2009. In situ testing in geomechanics. Taylor \& Francis, London and New York

16. Senneset K., Janbu N., Svano G. 1982. Strength and deformation parameters from cone penetration tests. In: Proc. ESOPT-2, Amsterdam, Balkema Publ., Rotterdam, 863-870.
17. Tumay M.T., Karasulu H., Mlynarek Z., Wierzbicki J. 2011. Effectiveness of piezo cone penetration test classification charts for identification of subsoil stratigraphy. In: Proc. of $12^{\text {th }}$ ECSMGE, Athens.

18. Wierzbicki J. 2010. Evaluation of subsoil overconsolidation by means of in situ tests in the context of its origin (in Polish). Rozprawy Naukowe nr 410. Wydawnictwo Uniwersytetu Przyrodniczego w Poznaniu. pp. 182.

19. Wierzbicki J. 2006. Parametry geotechniczne osadów tarasy zalewowej Wisły w rejonie Puław. [In:] Kałuża T. „Badania odporności hydraulicznej drzewostanów łęgowych w aspekcie racjonalnego zagospodarowania terenów zalewowych”. Raport z projektu badawczego KBN 0734/P06/2003/25.

20. Wierzbicki J., Smaga A. 2014. Repeatability analysis of geoengineering layers in river valley (in Polish). Przegląd Geologiczny, 62, 10/2, 721-726.

21. Wiłun Z. 2000. Zarys geotechniki (in Polish). Wyd. Komunikacji i Łączności, Warszawa. 